\title{
Coating of 2-Aminobenzimidiazole and 1-(o-Tolyl)biguanide Functionalized Silicas on Iron Sand Magnetic Material for Sorption of $\left[\mathrm{AuCl}_{4}\right]^{-}$
}

\author{
Nuryono $^{1,}$, Nur Mutia Rosiati ${ }^{1}$, Abraham L. Rettob $^{2}$, Suyanta ${ }^{1}$, and Yateman Arryanto ${ }^{1}$ \\ ${ }^{1}$ Department of Chemistry, Faculty of Mathematics and Natural Sciences, Universitas Gadjah Mada, \\ Sekip Utara, Yogyakarta 55281, Indonesia \\ ${ }^{2}$ Faculty of Teachers Training and Education, Musamus University, Jl. Kamizaun Mopah Lama, Merauke 99600, Indonesia
}

\section{*Corresponding author:}

email:nuryono_mipa@ugm.ac.id

Received: April 11, 2018

Accepted: July 26, 2018

DOI: $10.22146 / \mathrm{ijc} .34653$

\begin{abstract}
Two novel materials of 2-aminobenzimidiazole (AB) and 1-(otolyl)biguanide (TB) modified silicas coated on the iron sand magnetic material

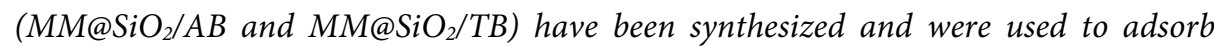
$\mathrm{Au}(\mathrm{III})$ from $\mathrm{Au} / \mathrm{Cu} / \mathrm{Ni}$ solution. Silica layering $\mathrm{MM}$ was modified with polyamino compounds via a sol-gel process using a sodium silicate solution, 3 chloropropyl trimethoxysilane (CPTS) and modifier compounds. Adsorption of Au(III) on $M M @ \mathrm{SiO}_{2} / \mathrm{AB}$ and $\mathrm{MM} @ \mathrm{SiO}_{2} / \mathrm{TB}$ was investigated in a batch system by varying $\mathrm{pH}$, initial concentration, contact time and the presence of other metal ions (Cu(II) and $\mathrm{Ni}(\mathrm{II})$ ). The results showed that $M M @ \mathrm{SiO}_{2} / \mathrm{AB}$ and $\mathrm{MM} @ \mathrm{SiO}_{2} / \mathrm{TB}$ were successfully synthesized through the sol-gel process using cross-linking agent CPTS. Adsorption of $\mathrm{Au}(\mathrm{III})$ on $\mathrm{MM} @ \mathrm{SiO}_{2} / \mathrm{AB}$ and $\mathrm{MM} @ S i O_{2} / \mathrm{TB}$ decreased with the increase of $\mathrm{pH}$ and followed the Langmuir isotherm models with adsorption capacity of 17.15 and $9.44 \mathrm{mg} / \mathrm{g}$, respectively. The adsorption kinetics fit to a pseudo-second-order model with the rate

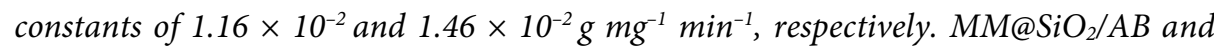
$\mathrm{MM} @ \mathrm{SiO}_{2} / \mathrm{TB}$ gave a high selectivity towards $\mathrm{Au}(\mathrm{III})$ in a mixture of $\mathrm{Cu}(\mathrm{II})$ and $\mathrm{Ni}(\mathrm{II})$. The desorption using thiourea $1 \mathrm{M}$ solution in $1 \mathrm{M} \mathrm{HCl}$ of metal ions showed that percentage of $\mathrm{Au}(\mathrm{III})$ desorbed was higher than that of $\mathrm{Cu}(\mathrm{II})$ and $\mathrm{Ni}(\mathrm{II})$.
\end{abstract}

Keywords: adsorption; iron sand; aminobenzimidiazole; tolylbiguanidine; gold

\section{- INTRODUCTION}

It is well known that gold ( $\mathrm{Au}$ ) exhibits many special characters and high economic value. Currently, the use of gold is not only as jewelry but also can be used in various fields, such as catalysis [1] and the electronic industry as components of Printed Circuit Board (PCB) [2-4]. The growth of the electronic industry leads to the increase of gold used in this field and the amount of electronic waste in the environment. The electronic components are not only gold but also other metals such as copper, zinc, and nickel. Consequently, a simple and efficient method for gold separation from other metals is required.

One of the gold separation methods as an ion, $\mathrm{Au}(\mathrm{III})$, is adsorption which has many advantages, including environmental-friendly, no hazardous waste, inexpensive, can be applied at a low concentration of metal ion [5] and the adsorbent can be used repeatedly [6]. Various types of adsorbents can be used in the process of $\mathrm{Au}(\mathrm{III})$ adsorption, such as nanoporous adsorbents [7], nanofiber membranes [8] and modified silica [5,9-11]. However, adsorption using this type of adsorbent is usually time-consuming in separation between adsorbent and filtrate.

One attempt to improve the effectiveness of silicabased materials as an adsorbent of $\mathrm{Au}$ (III) and other metal ions is by modifying it using organic functional groups [10]. The previous researcher proved that the functional groups of amines, monoamine, diamine or triamine are able to be used to modify the silica surface and to be used as a heavy metal adsorbent [5]. The amino groups can act as an electron-pair donor to the metal ions. As a result, the amine group is able to adsorb metal

Nuryono et al. 
ions [10-12]. The results showed that the adsorption capacity of $\mathrm{Cu}(\mathrm{II}), \mathrm{Ni}(\mathrm{II}), \mathrm{Pb}(\mathrm{II}), \mathrm{Cd}(\mathrm{II})$, and $\mathrm{Zn}(\mathrm{II})$ increases with increasing nitrogen atom number in the adsorbent [5]. However, the number of amino groups per molecule of modifying compound seems not significantly affect the adsorption capacity for $\mathrm{Au}$ (III). Sakti et al. [11] reported that the capacity of silica modified with aminopropyl silane to adsorb $\mathrm{Au}(\mathrm{III})$ was $134 \mathrm{mg} / \mathrm{g}$, while silica modified with arginine adsorbed $53 \mathrm{mg} / \mathrm{g}$ [12]. It seems that the environment of active sites including the presence of phenyl around the amino groups influences the capability in binding $\mathrm{Au}(\mathrm{III})$. Thus, two compounds containing both phenyl and amino groups namely 2aminobenzimidazole $(\mathrm{AB})$ and 1-(o-tolyl)biguanidine (TB) (Fig. 1) are investigated.

\section{- EXPERIMENTAL SECTION}

\section{Materials}

Iron sand magnetic material (MM) was separated from Iron sand collected from Bugel Beach, Kulonprogo, Yogyakarta, Indonesia referring to the procedure reported by Fahmiati et al. [18]. Ten grams of iron sand sample was separated using the external magnetic field to obtain MM. The attracted MM was sieved to 70 meshes and then washed with distilled water and dried at $80^{\circ} \mathrm{C}$. The MM was soaked with $10 \%$ HF solution and sonicated for $15 \mathrm{~min}$. The soaked MM was washed with distilled water and was dried at $80{ }^{\circ} \mathrm{C}$. The MM obtained was $81.6 \%$ of iron sand treated. Chemicals used for coating MM were purchased from Merck including $\mathrm{Na}_{2} \mathrm{SiO}_{3}$ solution (7.5-8.5\% $\mathrm{Na}_{2} \mathrm{O}$ and 25.5-28.5\% $\left.\mathrm{SiO}_{2}\right)$, 3chloropropyltrimetoxisilane (CPTS) and $\mathrm{NaCl}$, and 2aminobenzimidazole (AB) and 1-(o-tolyl)-biguanidine (TB) were supplied from Aldrich. Metal ions used for adsorption experiments were originated from $\mathrm{HAuCl}_{4}$, $\mathrm{NiCl}_{2} \cdot 6 \mathrm{H}_{2} \mathrm{O}$, and $\mathrm{CuCl}_{2} \cdot 2 \mathrm{H}_{2} \mathrm{O}$ (Merck) dissolved in $1 \mathrm{M}$ $\mathrm{HCl}$ solution, and chemicals for desorption were thiourea solution in $1 \mathrm{M} \mathrm{HCl}$.

\section{Instrumentation}

Fourier Transform Infrared (FTIR) Spectrophotometer (Shimadzu FTIR Prestige 21), X-ray Diffractometer (XRD) (Rigaku Multiflex), Vibrating Sample
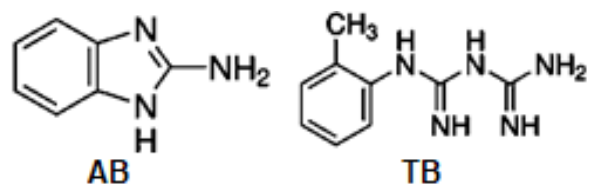

Fig 1. Structure of 2-aminobenzimidazole $(A B)$ and 1-(o-tolyl)biguanidine (TB)

Magnetometer (VSM) (VSM Oxford 1,2 T) were used to identify the presence of the functional groups, crystallinity, and magnetism, respectively. Atomic Absorption Spectrophotometer (AAS) (Analytic Jena contrAA 300) was used for analyzing $\mathrm{Fe}$ dissolved during stability test of products and the un-adsorbed metal ions.

\section{Procedure}

\section{Coating of MM and its characterization}

About $0.5 \mathrm{~g}$ of $\mathrm{MM}$ was activated with $1 \mathrm{~mL}$ of $1 \mathrm{M}$ $\mathrm{HCl}$ solution and the activated MM was added with $1 \mathrm{~mL}$ of sodium silicate solution to obtain Mixture 1 . Mixture 2 was prepared by mixing $1.8 \mathrm{~mL}$ of CPTS, $6 \mathrm{~mL}$ of DMF and modifiers (1.28 $\mathrm{g}$ of $\mathrm{AB}$ or $1.83 \mathrm{~g}$ of $\mathrm{TB}$ ). Mixture 2 was poured into Mixture 1 and then was added with $1 \mathrm{M} \mathrm{HCl}$ solution dropwise to form a gel. The formed gel was kept overnight and then dried in an oven at $80{ }^{\circ} \mathrm{C}$ for $4 \mathrm{~h}$. The dried product was grounded, washed with distilled water, and dried at $80^{\circ} \mathrm{C}$ for $4 \mathrm{~h}$. The obtained product was characterized by FTIR spectrophotometer, XRD, VSM. Besides, acidic stability was tested at various $\mathrm{pHs}$, and $\mathrm{pH}_{\mathrm{PzC}}$ was determined.

The acidic stability was carried out by mixing $10 \mathrm{mg}$ of samples and $10 \mathrm{~mL} \mathrm{pH}$ buffer solution at various $\mathrm{pHs}$ (1-6) prepared using $\mathrm{HCl}$ solution, $\mathrm{C}_{6} \mathrm{H}_{8} \mathrm{O}_{7} \cdot \mathrm{H}_{2} \mathrm{O}$, and $\mathrm{Na}_{3} \mathrm{C}_{6} \mathrm{H}_{5} \mathrm{O}_{7} \cdot 2 \mathrm{H}_{2} \mathrm{O}$. The mixture was shaken for $60 \mathrm{~min}$ and the filtrate was separated with an external magnetic field. The dissolved $\mathrm{Fe}$ ion was analyzed with AAS.

The $\mathrm{pH}_{\mathrm{PZC}}$ value of coated $\mathrm{MM}$ sample was determined by adjusting $\mathrm{pH}$ of $0.01 \mathrm{M} \mathrm{NaCl}$ solutions using $0.1 \mathrm{M} \mathrm{HCl}$ or $0.1 \mathrm{M} \mathrm{NaOH}$ solution to reach $\mathrm{pHs}$ of 1-10. About $10 \mathrm{mg}$ of coated MMs was put into each container of $\mathrm{NaCl}$ solution with different $\mathrm{pH}$. The mixtures were shaken for $60 \mathrm{~min}$, kept for 3 days and then the final $\mathrm{pH}$ was measured. 


\section{Adsorption of metal ions}

Adsorption was carried out in a batch system by adding $10 \mathrm{mg}$ of adsorbent in $10 \mathrm{~mL}$ of buffer solution containing $\mathrm{Au}$ (III) $50 \mathrm{mg} / \mathrm{L}$. The mixture was stirred for

$1 \mathrm{~h}$ and the adsorbent was separated with an external magnet. The amount of $\mathrm{Au}$ (III) not adsorbed was analyzed with AAS, and the adsorbed $\mathrm{Au}(\mathrm{III})$ was calculated using Eq. (1):

$\mathrm{Q}=\frac{\left(\mathrm{C}_{0}-\mathrm{C}_{\mathrm{e}}\right) \mathrm{V}}{\mathrm{w}}$

where Q represents the amount of $\mathrm{Au}(\mathrm{III})$ adsorbed (mg $\left.\mathrm{g}^{-1}\right) ; \mathrm{C}_{0}$ and $\mathrm{C}_{\mathrm{e}}$ are the initial and the final concentrations of the metal ion $\left(\mathrm{mg} \mathrm{L}^{-1}\right)$, respectively; $\mathrm{W}$ is the mass of the adsorbent ( $\mathrm{g}$ ), and $\mathrm{V}$ is the volume of the metal ion solution (L).

The $\mathrm{pH}$ was adjusted and varied from 1.0 to 6.0. An analog work of the adsorption was performed by varying the $\mathrm{Au}(\mathrm{III})$ concentration, in a range of $5-75 \mathrm{mg} / \mathrm{L}$, at optimum $\mathrm{pH}$. The resulted data was evaluated using Langmuir and Freundlich isotherm models. In addition, adsorption in various contact times (15-240 $\mathrm{min}$ ) at optimum $\mathrm{pH}$ and $\mathrm{Au}$ (III) concentration was conduct and the kinetics were studied using models of pseudo-firstorder and pseudo-second-order. Adsorption of $\mathrm{Au}(\mathrm{III})$ in the presence of other metal ions, $\mathrm{Cu}$ (II) and $\mathrm{Ni}(\mathrm{II})$, was also conducted. About $10 \mathrm{~g}$ coated MM was mixed with $10 \mathrm{~mL}$ metal ion mixture of $\mathrm{Au}$ (III)/Cu(II)/Ni(II) with the various concentration ratios of $\mathrm{Au}$ (III) $(20 \mathrm{mg} / \mathrm{L})$ to other metal ions $(20,40$, and $60 \mathrm{mg} / \mathrm{L})$. The adsorption selectivity of coated $\mathrm{MM}$ to $\mathrm{Au}(\mathrm{III})$ was presented as a selectivity coefficient of $\mathrm{Au}(\mathrm{III})$ to another ion $\mathrm{M}\left(\alpha_{\mathrm{Au} / \mathrm{M}}\right)$ calculated using Eq. (2).

$\alpha_{\mathrm{Au} / \mathrm{M}}=\frac{\mathrm{D}_{\mathrm{Au}}}{\mathrm{D}_{\mathrm{M}}}, \mathrm{D}=\frac{\mathrm{Q}}{\mathrm{C}_{\mathrm{e}}}$

where D represents the distribution coefficient of ion, $\mathrm{Q}$ is capacity and $\mathrm{C}_{e}$ concentration of ion at equilibrium.

\section{Desorption of metal ions}

Amount of $10 \mathrm{mg}$ adsorbent was put into a bottle containing of $\mathrm{Au}(\mathrm{III}), \mathrm{Cu}(\mathrm{II}), \mathrm{Ni}(\mathrm{II})$ with various concentrations ratios $(\mathrm{Au}(\mathrm{III}): \mathrm{Cu}(\mathrm{II}): \mathrm{Ni}(\mathrm{II})=20: 0: 0$; 20:20:20; 20:40:20 and 20:20:40 $\mathrm{mg} / \mathrm{L}$ ) and then shaken for $60 \mathrm{~min}$. The adsorbent was separated with an external magnet and the filtrate was analyzed using AAS. The adsorbent was dried at $40^{\circ} \mathrm{C}$ and then $10 \mathrm{~mL}$ thiourea 1 $\mathrm{M}$ in $1 \mathrm{M} \mathrm{HCl}$ solution added into it and shaken for 60 min. The adsorbent was separated with an external magnet and the filtrate was measured by AAS.

\section{- RESULTS AND DISCUSSION}

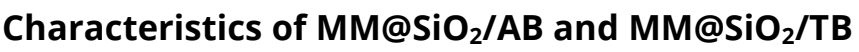

\section{Functional groups}

The presence of functional groups in the products has been identified based on the IR spectra as presented in Fig. 2. From the figure seems that stretching vibration of M-O-M ( $\mathrm{M}=\mathrm{Si}$ or $\mathrm{Ti})$ is observed at $1041-1057 \mathrm{~cm}^{-1}$. The absorption band at $3448 \mathrm{~cm}^{-1}$ appears from stretching of $-\mathrm{OH}$ bond [18].

Vibration band at $571 \mathrm{~cm}^{-1}$ comes from the absorption of Fe-O bond [15]. The intensity of this peak decreases after MM coating. This is due to the presence of layer on MM surface. The appearance of the band at $463-471 \mathrm{~cm}^{-1}$ indicates the presence of $\mathrm{Si}-\mathrm{O}-\mathrm{Si}$. Stretching vibration of $\mathrm{Si}-\mathrm{O}-\mathrm{Si}$ is observed at 787-802 and $1039-1088 \mathrm{~cm}^{-1}$. Stretching vibration of $\mathrm{Si}-\mathrm{OH}$ is identified at $910-941 \mathrm{~cm}^{-1}$ [19]. The absorption bands at 1628-1636 and 3418-3449 $\mathrm{cm}^{-1}$ in coated MM spectra come from bending and stretching of $-\mathrm{OH}$ in $\mathrm{Fe}-\mathrm{OH}$ and $\mathrm{Si}-\mathrm{OH}$.

Using 3-chloropropyltrimetoxisilane (CPTS) as a cross-linking group between silica and functional groups causes the presence of absorption band from bending of $-\mathrm{CH}_{2}$ at $1442 \mathrm{~cm}^{-1}$. The absorption band at

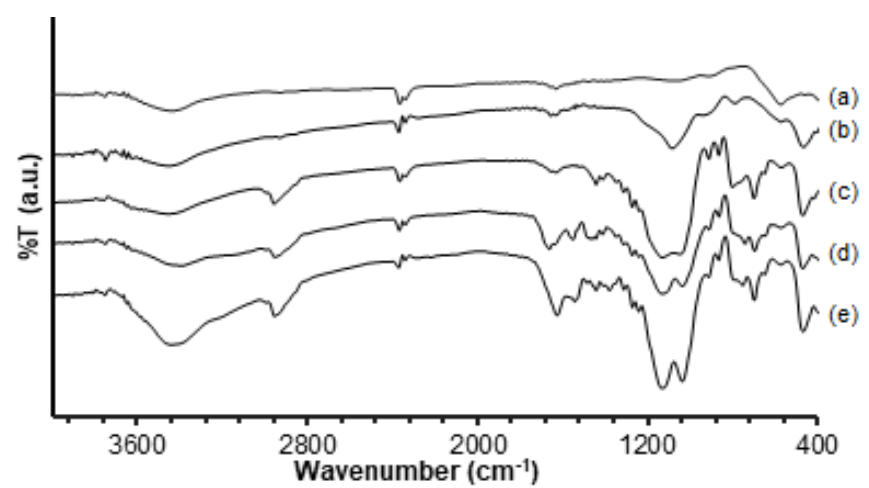

Fig 2. FTIR spectra of (a) MM after activation with HF, (b) $\mathrm{MM} @ S i O_{2}$, (c) $\mathrm{MM} @ S i O_{2} / \mathrm{CPTS}$, (d) $\mathrm{MM} @ S i O_{2} / \mathrm{AB}$

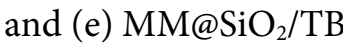




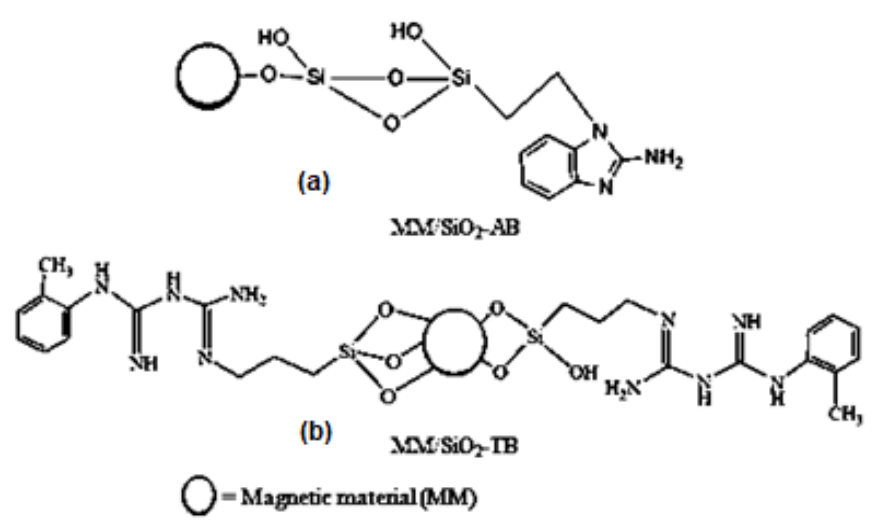

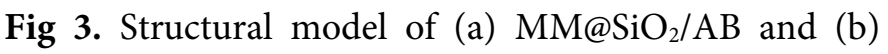
$\mathrm{MM} @ S i O_{2} / \mathrm{TB}$

$1126 \mathrm{~cm}^{-1}$ is identified from stretching of $\mathrm{Si}-\mathrm{CH}_{2}$. The presence of C-H results in absorption band at $2955 \mathrm{~cm}^{-1}$ as asymmetric stretching vibration [19]. Therefore, those peaks are not detected on $\mathrm{MM}$ and $\mathrm{MM} / \mathrm{SiO}_{2}$.

The appearance of $\mathrm{C}=\mathrm{C}$ benzene aromatic ring stretching vibration band at $\mathrm{MM} @ \mathrm{SiO}_{2} / \mathrm{AB}$ indicates that $A B$ ligand was successfully coated on MM. This is evidenced by the presence of $\mathrm{C}=\mathrm{N}$ stretching vibration band of the imidazole ring at $1558 \mathrm{~cm}^{-1}$. The observed bands around $3300 \mathrm{~cm}^{-1}$ correspond to stretching of $-\mathrm{OH}$ and $-\mathrm{NH}[15]$.

The success of coating with $\mathrm{TB}$ to form $\mathrm{MM} @ \mathrm{SiO}_{2} / \mathrm{TB}$ was proved by the presence of $\mathrm{C}-\mathrm{N}$ stretching vibration at $1381 \mathrm{~cm}^{-1}$. Stretching vibration of the $\mathrm{C}=\mathrm{C}$ benzene ring is detected at $1543 \mathrm{~cm}^{-1}$. This band coincides with the absorption band of $\mathrm{C}=\mathrm{N}$ stretching. The absorption band at $1628 \mathrm{~cm}^{-1}$ derived from multiple vibration bands; $-\mathrm{OH},-\mathrm{NH}$ and $\mathrm{C}=\mathrm{C}$ aromatic. The presence of a band at $3426 \mathrm{~cm}^{-1}$ originates from the stretching of $-\mathrm{OH}$ and $-\mathrm{NH}$ [15]. The FTIR analysis results show the presence of $\mathrm{Fe}-\mathrm{O}, \mathrm{Si}-\mathrm{C}, \mathrm{C}-\mathrm{N}$ and $\mathrm{Si}-\mathrm{O}-\mathrm{Si}$ bonds. This may form the structure model of $\mathrm{MM} @ \mathrm{SiO}_{2} / \mathrm{AB}$ and $\mathrm{MM} @ S i O_{2} / \mathrm{TB}$ as presented in Fig. 3 .

\section{Crystallinity}

The XRD patterns of uncoated and coated MMs are shown in Fig. 4. It describes the type of iron oxide containing in MM. The iron oxide dominant phase of $\mathrm{MM}$ is magnetite according to Powder Diffraction File (PDF) No. 19-0629. Silica iron oxide $\left(\mathrm{Fe}_{2,95} \mathrm{Si}_{0,05} \mathrm{O}_{4}\right)$

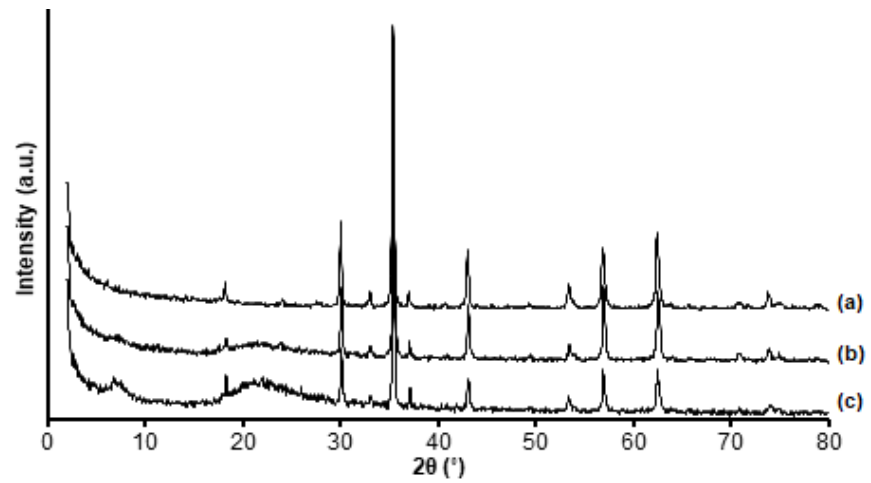

Fig 4. XRD patterns of (a) MM after activation with $\mathrm{HF}$, (b) $\mathrm{MM} @ S i O_{2} / \mathrm{AB}$ and (c) $\mathrm{MM} @ S i O_{2} / \mathrm{TB}$

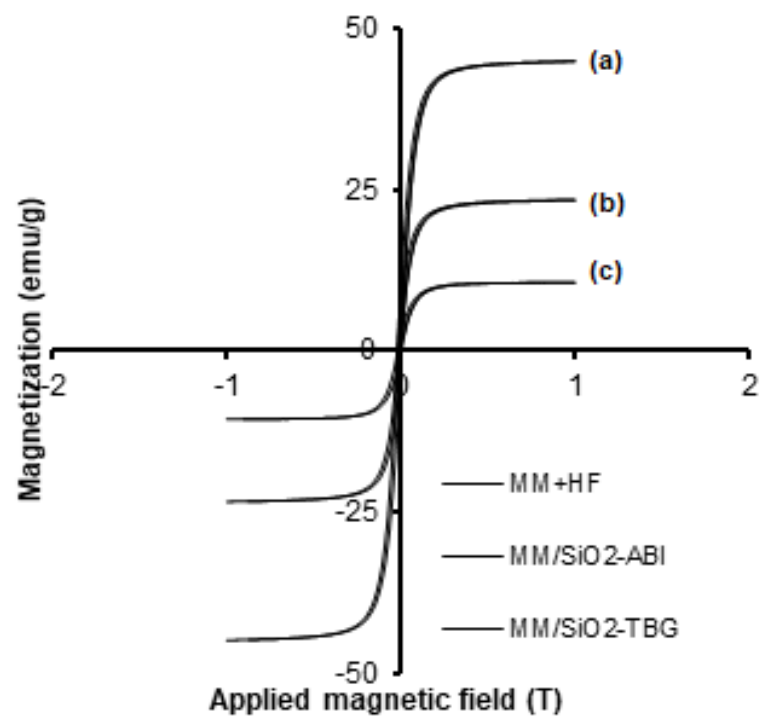

Fig 5. The magnetization hysteresis loop of (a) MM after

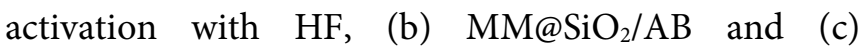
$\mathrm{MM} @ S i O_{2} / \mathrm{TB}$

Table 1. Magnetic properties of uncoated and coated MM

\begin{tabular}{cccc}
\hline Material & $\mathrm{M}_{\mathrm{s}}(\mathrm{emu} / \mathrm{g})$ & $\mathrm{M}_{\mathrm{r}}(\mathrm{emu} / \mathrm{g})$ & $\mathrm{H}_{\mathrm{c}}\left(\times 10^{-2} \mathrm{~T}\right)$ \\
\hline $\mathrm{HF}$ treated $\mathrm{MM}$ & 44.90 & 10.90 & 1.69 \\
$\mathrm{MM} @ \mathrm{SiO}_{2} / \mathrm{AB}$ & 23.30 & 5.41 & 1.93 \\
${\mathrm{MM} @ \mathrm{SiO}_{2} / \mathrm{TB}}$ & 10.60 & 2.23 & 1.86 \\
\hline
\end{tabular}

according to PDF No. 52-1140, titania iron oxide $\left(\left(\left(\mathrm{Fe}_{2,5} \mathrm{Ti}_{0,5}\right)_{1,04}\right) \mathrm{O}_{4}\right)$ according to PDF No. 51-1587 and ilmenite $\left(\mathrm{Fe}_{2} \mathrm{TiO}_{3}\right)$ according to PDF No. 29-0733 are also detected. The decrease of MM diffraction peaks intensity and the appearance of new peaks are observed after coating 
of MM with silica hybrid. The presence of broad peaks at 6.04 and $20.48^{\circ}$ on coated MM XRD patterns indicate that MM has been successfully coated with silica [20].

\section{Magnetism}

Magnetic properties of bare MM and coated MM were measured at room temperature and the results are shown in Fig. 5. It reveals that coating of MM reduces the maximum saturation magnetization $\left(\mathrm{M}_{\mathrm{s}}\right)$ of $\mathrm{MM}$ from $44.90 \mathrm{emu} / \mathrm{g}$ to $23.30 \mathrm{emu} / \mathrm{g}$ for $\mathrm{MM} @ S i O_{2} / \mathrm{AB}$ and to

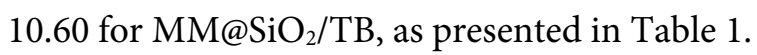

It is probably due to the presence of layer on MM surface while these silica hybrid layers have no magnetic property [6,14,21]. A lower $\mathrm{M}_{\mathrm{s}}$ value of ${\mathrm{MM} @ S i \mathrm{O}_{2} / \mathrm{TB}}$ may be explained because of a higher molecular weight of

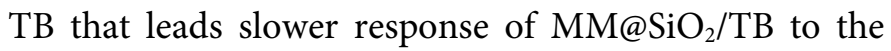
external magnetic field than that of $\mathrm{MM} @ S i O_{2} / \mathrm{AB}$.

\section{Stability in acidic condition}

The stability test of adsorbents at various acidic $\mathrm{pHs}$ is evaluated for detecting the amount of $\mathrm{Fe}$ ions dissolved from coated MM. The decrease of Fe content in MM may reduce the magnetic properties of adsorbent. Fig. 6 shows that dissolved $\mathrm{Fe}$ ions from coated $\mathrm{MM}$ are not more than 2.5\%. The insignificant difference of the dissolved $\mathrm{Fe}$ at various acidic $\mathrm{pHs}$ indicates that $\mathrm{MM} @ S i O_{2} / \mathrm{AB}$ and

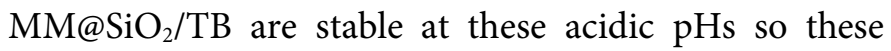
adsorbents could be used for adsorption in these $\mathrm{pHs}$ range.

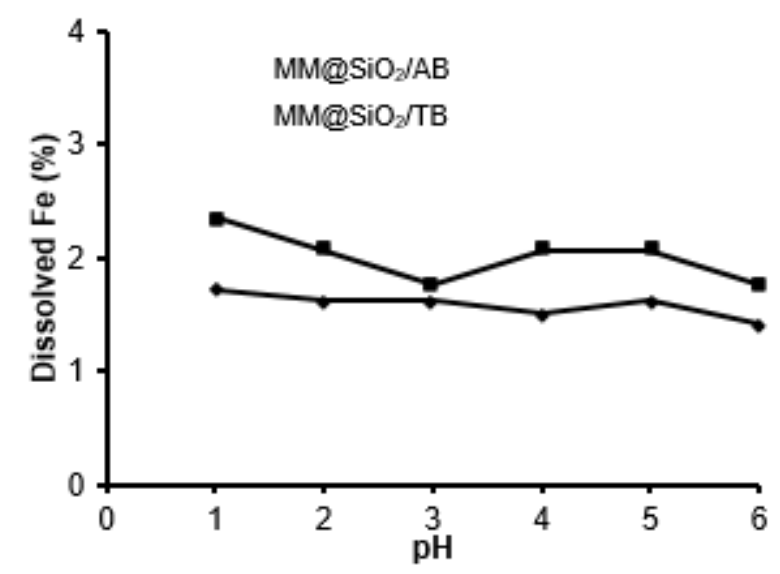

Fig 6. The effect of $\mathrm{pHs}$ to dissolved $\mathrm{Fe}$ (\%) of $\mathrm{MM} @ \mathrm{SiO}_{2} / \mathrm{AB}$ and $\mathrm{MM} @ S i O_{2} / \mathrm{TB}$

\section{pH $H_{P Z C}$ value}

Value of $\mathrm{pH}_{\mathrm{PzC}}$ was investigated to determine the type of adsorbent surface charge at a certain $\mathrm{pH}$. The increase of solution $\mathrm{pH}$ corresponds to the protonated functional groups on the adsorbent surface so that is charged positively. On the other hand, if the final solution $\mathrm{pH}$ is lower than initial solution $\mathrm{pH}$, it indicates the increase of $\mathrm{H}^{+}$ions in solution. This phenomenon proves the occurrence of functional groups deprotonation on the adsorbent surface. Fig. 7 shows

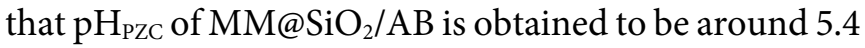

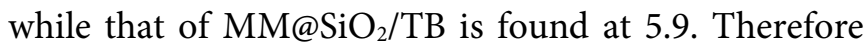
these adsorbents are positively charged below these $\mathrm{pHs}$.

These values are lower than $\mathrm{pH}_{\mathrm{PZC}}$ of bare magnetite which is found to be around 8.2 [21], indicating $\mathrm{MM}$ were covered by silica hybrid. A higher pHpzc value of $\mathrm{MM@SiO}_{2} / \mathrm{TB}$ than that of $\mathrm{MM} @ \mathrm{SiO}_{2} / \mathrm{AB}$ could be expected since the number of amine groups on $\mathrm{TB}$ ligand is more than it on $\mathrm{AB}$ ligand. Therefore the amount of $\mathrm{H}^{+}$ions required for protonating active sites of the adsorbent surface on $\mathrm{MM} @ \mathrm{SiO}_{2} / \mathrm{TB}$ is higher than it on $\mathrm{MM} @ S i O_{2} / \mathrm{AB}$.

\section{Adsorption}

\section{Effect of pH on Au(III) adsorption}

To investigate the effect of $\mathrm{pH}$ on $\mathrm{Au}(\mathrm{III})$ adsorption, the adsorption was done at various $\mathrm{pH}$ from 1.0 to 6.0. The reduction tendency of adsorption capacity

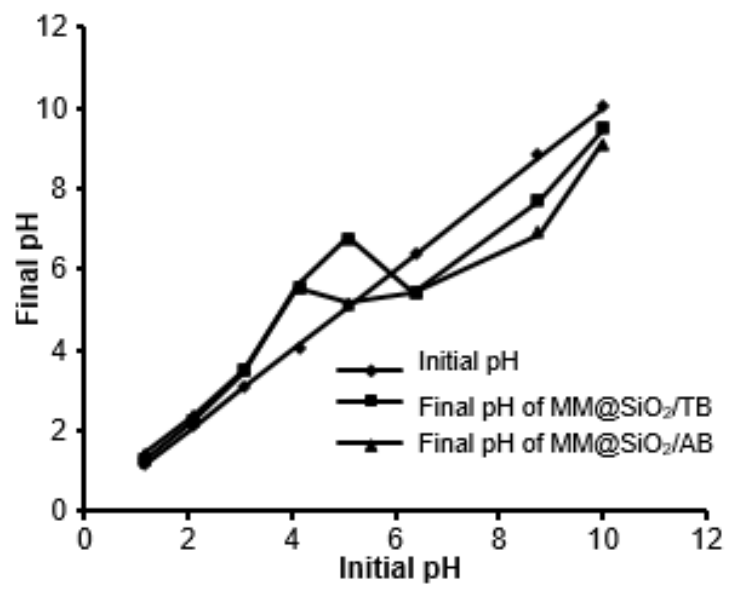

Fig 7. $\mathrm{pH}_{\mathrm{PZC}}$ of $\mathrm{MM} @ \mathrm{SiO}_{2} / \mathrm{AB}$ and ${\mathrm{MM} @ S i \mathrm{O}_{2} / \mathrm{TB}}$ 


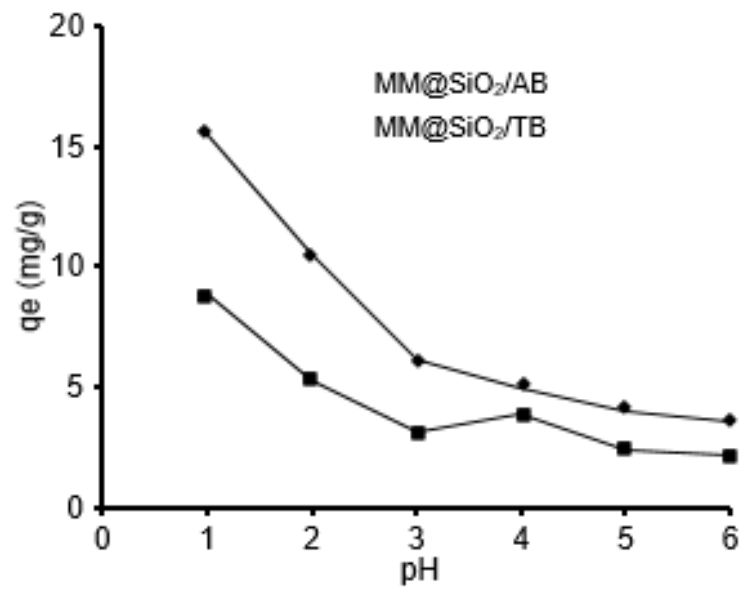

Fig 8. The effect of $\mathrm{pH}$ to adsorbed $\mathrm{Au}(\mathrm{III})$ on $\mathrm{MM} @ \mathrm{SiO}_{2} / \mathrm{AB}$ and ${\mathrm{MM} @ S i \mathrm{O}_{2} / \mathrm{TB}}$

is observed with the increase of solution $\mathrm{pH}$ (Fig. 8).

The highest amount of adsorbed $\mathrm{Au}$ (III) on both adsorbents is obtained at a $\mathrm{pH}$ of 1.0 with adsorption capacity of $\mathrm{MM@SiO}_{2} / \mathrm{AB}$ is $15.58 \mathrm{mg} / \mathrm{g}$ while that of

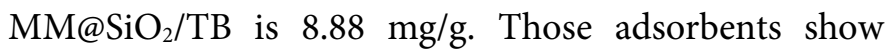
higher capacity in comparison to unmodified $\mathrm{MM} @ \mathrm{SiO}_{2}$ $2.61 \mathrm{mg} / \mathrm{g}$ at the range of $\mathrm{pH}$ tested. This optimum $\mathrm{pH}$ may be obtained since the amine groups on these adsorbents has been protonated perfectly so the amount of $\mathrm{Au}(\mathrm{III})$ that interact with the active sites of adsorbent

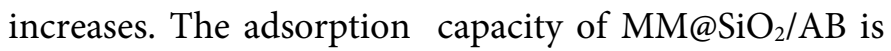
greater than that of $\mathrm{MM} @ \mathrm{SiO}_{2} / \mathrm{TB}$. It is due to the higher of amine groups number on $\mathrm{TB}$ ligand which has the near distance between itself leads to steric hindrance when $\mathrm{Au}$ (III) adsorbed in high amount. $\mathrm{Au}$ (III) exist in solution as $\left[\mathrm{AuCl}_{4}\right]^{-}$when $\mathrm{pH}$ is below 3 [22] while coated MM positively charged at $\mathrm{pH}$ below theirs $\mathrm{pH}_{\text {PZc }}$. This indicates that the $\mathrm{Au}(\mathrm{III})$ adsorption on $\mathrm{MM} @ S i O_{2} / \mathrm{AB}$ and $\mathrm{MM} @ \mathrm{SiO}_{2} / \mathrm{TB}$ could be attributed to the electrostatic attraction. The positive charge of adsorbents surface increases with the decrease of $\mathrm{pH}$. Thus the maximum adsorption capacity is obtained at lower $\mathrm{pH}$ and then the solution $\mathrm{pH}$ was set at 1.0 in the following experiments.

\section{Adsorption isotherms}

It is known that the maximum adsorption capacity of $\mathrm{MM} @ S i O_{2} / \mathrm{AB}$ and $\mathrm{MM} @ \mathrm{SiO}_{2} / \mathrm{TB}$ is measured at the initial $\mathrm{Au}$ (III) concentration of $20 \mathrm{mg} / \mathrm{L}$ (Fig. 9). The

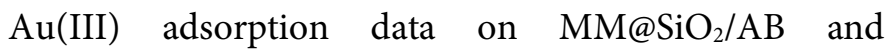
$\mathrm{MM} @ \mathrm{SiO}_{2} / \mathrm{TB}$ were analyzed with Langmuir and

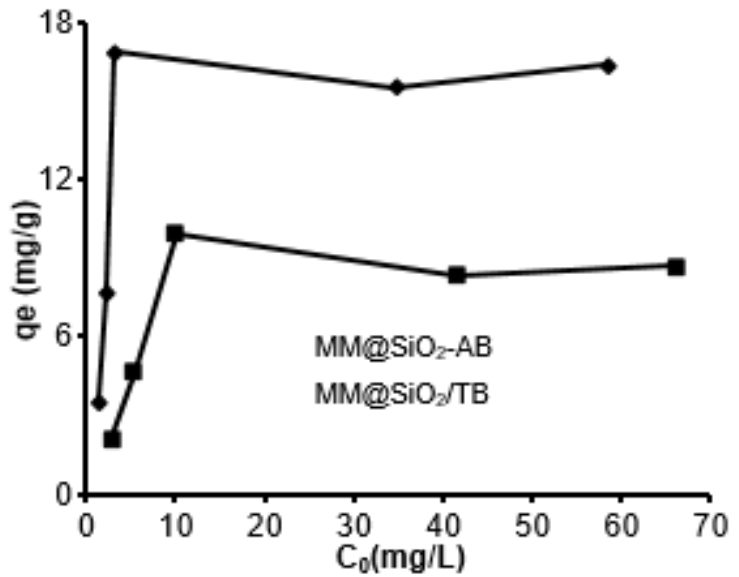

Fig 9. The effect of initial concentration on adsorbed

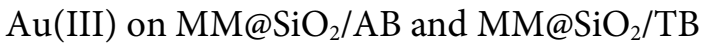

Freundlich isotherm models. Langmuir adsorption isotherm model can be written as Eq. (3).

$\frac{\mathrm{C}_{\mathrm{e}}}{\mathrm{q}_{\mathrm{e}}}=\frac{1}{\mathrm{q}_{\max }} \mathrm{C}_{\mathrm{e}}+\frac{1}{\mathrm{q}_{\max } \mathrm{K}_{\mathrm{L}}}$

where $\mathrm{q}_{\mathrm{e}}(\mathrm{mg} / \mathrm{g})$ and $\mathrm{C}_{\mathrm{e}}(\mathrm{mg} / \mathrm{L})$ are the amount adsorbed and concentration of $\mathrm{Au}(\mathrm{III})$ at equilibrium, respectively, $\mathrm{q}_{\max }$ is maximum adsorption capacity ( $\mathrm{mg} / \mathrm{g}$ ) and $\mathrm{K}_{\mathrm{L}}$ is Langmuir constant relating to the affinity of binding sites ( $\mathrm{L} / \mathrm{mg}$ ). The values of $\mathrm{q}_{\max }$ and $\mathrm{K}_{\mathrm{L}}$ can be determined from the slope and intercept of $\mathrm{C}_{e}$ versus $\mathrm{C}_{\mathrm{e}} / \mathrm{q}_{\mathrm{e}}$ plot. Freundlich adsorption isotherm empirically can be expressed in Eq. (4).

$\ln \mathrm{q}_{\mathrm{e}}=\frac{1}{\mathrm{n}} \ln \mathrm{C}_{\mathrm{t}}+\ln \mathrm{K}_{\mathrm{F}}$

where $\mathrm{K}_{\mathrm{F}}$ is Freundlich constant related to adsorption capacity of adsorbent and $\mathrm{n}$ is the Freundlich exponent related to adsorption intensity. The values of $\mathrm{K}_{\mathrm{F}}$ and $n$ can be calculated from the slope and intercept of $\ln \mathrm{C}_{\mathrm{t}} \mathrm{vs}$ $\ln \mathrm{q}_{\mathrm{e}}$ plot.

Langmuir and Freundlich parameters and regression coefficient are shown in (Table 2). The linear regression coefficients $\left(\mathrm{R}^{2}\right)$ for the Langmuir model (more than 0.9823) are higher than that for Freundlich (less than 0.6036). Those values indicate that $\mathrm{Au}(\mathrm{III})$ adsorption on $\mathrm{MM} @ S i O_{2} / \mathrm{AB}$ and $\mathrm{MM} @ S i O_{2} / \mathrm{TB}$ fit with the Langmuir model and implied that the $\mathrm{Au}(\mathrm{III})$ adsorption on these adsorbent occurs in a single monolayer. Adsorption of $\mathrm{Au}(\mathrm{III})$ on these adsorbents

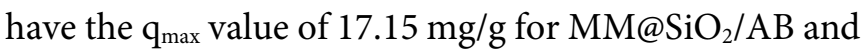


that of $9.44 \mathrm{mg} / \mathrm{g}$ for $\mathrm{MM} @ \mathrm{SiO}_{2} / \mathrm{TB}$. These $\mathrm{q}_{\max }$ values are higher than that for $\mathrm{MM} / \mathrm{SiO}_{2}(2.71 \mathrm{mg} / \mathrm{g})$ showing the effect of coating MM with functional groups added. It may be understood because of two factors: firstly, the steric hindrance between $\mathrm{Au}(\mathrm{III})$ adsorbed. Secondly, the competition between $\left[\mathrm{AuCl}_{4}\right]^{-}$anion and $\mathrm{Cl}^{-}$ion from the buffer solution to interact with active sites of adsorbent.

\section{Adsorption kinetics}

Adsorption kinetics is evaluated by varying contact time of $\mathrm{Au}$ (III) adsorption. The result shows that the adsorption of $\mathrm{Au}(\mathrm{III})$ is fast and reaches equilibrium within $45 \mathrm{~min}$ for both adsorbents (Fig. 10). Pseudo-first order and pseudo-second-order kinetic models are applied to evaluate the kinetics. Pseudo-first order and pseudo-second-order model are shown below.

$\log \left(\mathrm{q}_{\mathrm{e}}-\mathrm{q}_{\mathrm{t}}\right)=\log \mathrm{q}_{\mathrm{e}}-\frac{\mathrm{k}_{1}}{2.303} \mathrm{t}$

$\frac{\mathrm{t}}{\mathrm{q}_{\mathrm{t}}}=\frac{1}{\mathrm{q}_{\mathrm{e}}} \mathrm{t}+\frac{1}{\mathrm{~h}}$

$\mathrm{k}_{2}=\frac{\mathrm{h}}{\mathrm{q}_{\mathrm{e}}^{2}}$

where $\mathrm{q}_{\mathrm{e}}$ and $\mathrm{q}_{\mathrm{t}}$ are the amounts of $\mathrm{Au}$ (III) adsorbed at equilibrium and time $t$, respectively; $k_{1}$ and $k_{2}$ are adsorption rate constant for pseudo-first-order and pseudo-second-order kinetics, respectively. The value of $k_{1}$ and $k_{2}$ can be obtained by plotting curves of $t$ versus $\log \left(\mathrm{q}_{\mathrm{e}}-\mathrm{q}_{\mathrm{t}}\right)$ and $\mathrm{t}$ versus $\mathrm{t} / \mathrm{q}_{\mathrm{t}}$.

Table 3 shows that $\mathrm{Au}(\mathrm{III})$ adsorption on $\mathrm{MM} @ S i O_{2} / \mathrm{AB}$ and $\mathrm{MM} @ S i O_{2} / \mathrm{TB}$ follows the kinetic model of pseudo-second order. The adsorption rate

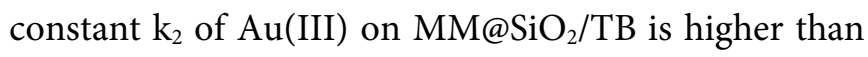

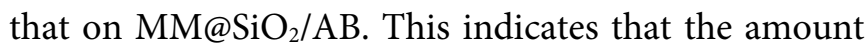
of $\mathrm{Au}(\mathrm{III})$ adsorbed on a constant mass of ${\mathrm{MM} @ \mathrm{SiO}_{2} / \mathrm{TB}}$

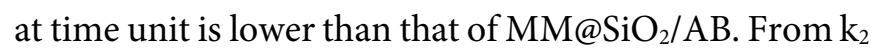
value, also known that $\mathrm{MM} @ \mathrm{SiO}_{2} / \mathrm{AB}$ has a greater

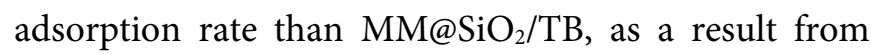
inversely proportional to $\mathrm{k}_{2}$ value. This result supported the kinetics models reported by previous researchers revealing that $\mathrm{Au}(\mathrm{III})$ adsorption on adsorbent follows pseudo-second-order with $\mathrm{k}_{2}$ value in the order of $10^{-2}$ $\mathrm{g} / \mathrm{mg} \min [3,16]$.

\section{Adsorption selectivity}

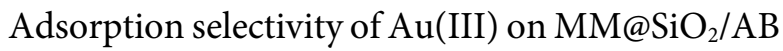
and $\mathrm{MM} @ \mathrm{SiO}_{2} / \mathrm{TB}$ in metal ions mixture was conducted by adsorbing metal ions at constant $\mathrm{Au}(\mathrm{III})$ concentration

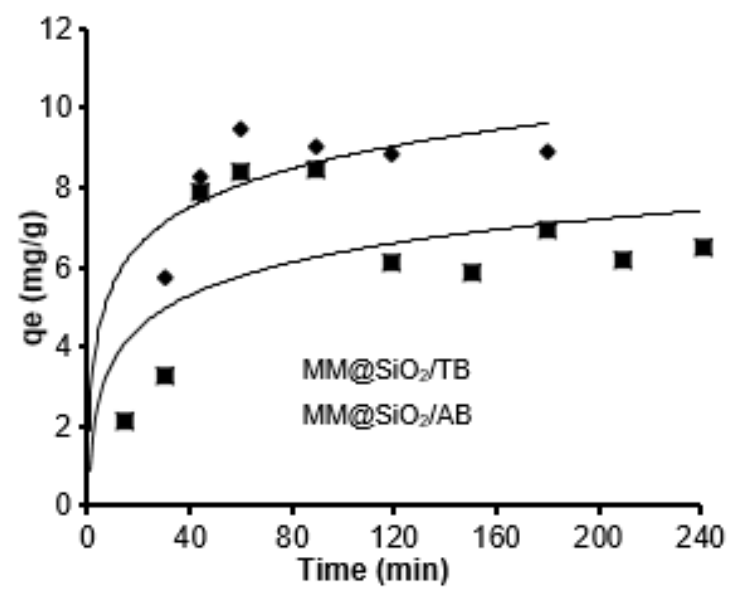

Fig 10. The effect of adsorption time to adsorbed $\mathrm{Au}(\mathrm{III})$

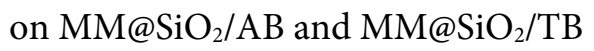

Table 2. Adsorption isotherm parameters of $\mathrm{Au}(\mathrm{III})$ on $\mathrm{MM} @ \mathrm{SiO}_{2} / \mathrm{AB}$ and $\mathrm{MM} @ S i O_{2} / \mathrm{T}$

\begin{tabular}{ccccccc}
\hline \multirow{2}{*}{ Adsorbent } & \multicolumn{3}{c}{ Langmuir } & \multicolumn{3}{c}{ Freundlich } \\
\cline { 2 - 7 } & $\mathrm{q}_{\max }(\mathrm{mg} / \mathrm{g})$ & $\mathrm{K}_{\mathrm{L}}(\mathrm{L} / \mathrm{mg})$ & $\mathrm{R}^{2}$ & $\mathrm{~K}_{\mathrm{F}}(\mathrm{mg} / \mathrm{g})$ & $\mathrm{n}$ & $\mathrm{R}^{2}$ \\
\hline $\mathrm{MM} @ \mathrm{SiO}_{2} / \mathrm{AB}$ & 17.15 & 0.33 & 0.9935 & 5.78 & 3.48 & 0.4959 \\
${\mathrm{MM} S \mathrm{SiO}_{2} / \mathrm{TB}}^{9.44}$ & 0.19 & 0.9823 & 2.23 & 2.68 & 0.6036 \\
\hline
\end{tabular}

Table 3. Adsorption kinetics parameters of $\mathrm{Au}(\mathrm{III})$ on $\mathrm{MM} @ \mathrm{SiO}_{2} / \mathrm{AB}$ and $\mathrm{MM}_{\mathrm{MSiO}} / \mathrm{TB}$

\begin{tabular}{ccccccc}
\hline & \multicolumn{3}{c}{ Pseudo first-order } & \multicolumn{3}{c}{ Pseudo second-order } \\
\cline { 2 - 7 } Adsorbent & $\begin{array}{c}\mathrm{k}_{1} \\
\left(\mathrm{~min}^{-1}\right)\end{array}$ & $\begin{array}{c}\mathrm{q}_{\mathrm{e}} \\
(\mathrm{mg} / \mathrm{g})\end{array}$ & $\mathrm{R}^{2}$ & $\begin{array}{c}\mathrm{k}_{2} \\
\left(\mathrm{~g} \mathrm{mg}^{-1} \mathrm{~min}^{-1}\right)\end{array}$ & $\begin{array}{c}\mathrm{q}_{\mathrm{e}} \\
(\mathrm{mg} / \mathrm{g})\end{array}$ & $\mathrm{R}^{2}$ \\
\hline $\mathrm{MM} @ \mathrm{SiO}_{2} / \mathrm{AB}$ & $1.38 \times 10^{-2}$ & 1.79 & 0.6503 & $1.16 \times 10^{-2}$ & 9.52 & 0.9884 \\
$\mathrm{MM} @ \mathrm{SiO}_{2} / \mathrm{TB}$ & $1.15 \times 10^{-3}$ & 1.42 & 0.0061 & $1.46 \times 10^{-2}$ & 6.83 & 0.9486 \\
\hline
\end{tabular}




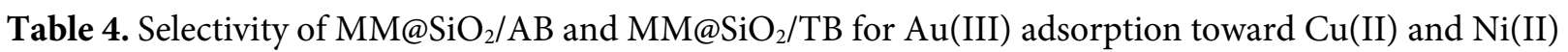

\begin{tabular}{|c|c|c|c|c|c|c|c|c|}
\hline \multirow[t]{2}{*}{ Adsorbent } & \multicolumn{3}{|c|}{ Initial concentration $(\mathrm{mg} / \mathrm{L})$} & \multicolumn{3}{|c|}{$\mathrm{D}(\mathrm{L} / \mathrm{g})$} & \multirow{2}{*}{$\alpha_{\mathrm{Au} / \mathrm{Cu}}$} & \multirow{2}{*}{$\alpha_{\mathrm{Au} / \mathrm{Ni}}$} \\
\hline & $\mathrm{Au}(\mathrm{III})$ & $\mathrm{Cu}(\mathrm{II})$ & $\mathrm{Ni}(\mathrm{II})$ & $\mathrm{Au}(\mathrm{III})$ & $\mathrm{Cu}(\mathrm{II})$ & $\mathrm{Ni}(\mathrm{II})$ & & \\
\hline \multirow{5}{*}{ 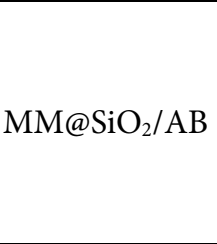 } & 20 & 20 & 20 & 53.67 & 1.52 & 2.64 & 35.21 & 20.36 \\
\hline & 20 & 20 & 40 & 36.27 & 1.60 & 2.72 & 22.67 & 13.33 \\
\hline & 20 & 20 & 60 & 34.65 & 1.52 & 2.87 & 22.73 & 12.07 \\
\hline & 20 & 40 & 20 & 13.39 & 1.46 & 2.20 & 9.14 & 6.09 \\
\hline & 20 & 60 & 20 & 13.91 & 1.32 & 2.48 & 10.91 & 5.61 \\
\hline \multirow{5}{*}{$\mathrm{MM} @ S i O_{2} / \mathrm{TB}$} & 20 & 20 & 20 & 12.16 & 2.68 & 2.01 & 4.53 & 6.05 \\
\hline & 20 & 20 & 40 & 11.36 & 2.68 & 1.98 & 4.23 & 5.74 \\
\hline & 20 & 20 & 60 & 7.00 & 2.78 & 2.17 & 2.52 & 3.22 \\
\hline & 20 & 40 & 20 & 13.07 & 2.21 & 1.52 & 5.90 & 8.60 \\
\hline & 20 & 60 & 20 & 18.42 & 1.85 & 1.74 & 9.98 & 10.57 \\
\hline
\end{tabular}

Table 5. Percentage of metal ion desorbed in a mixture of $\mathrm{Au}(\mathrm{III}), \mathrm{Cu}(\mathrm{II})$ and $\mathrm{Ni}$ (II)

\begin{tabular}{|c|c|c|c|c|c|c|c|c|c|c|c|c|}
\hline \multirow[t]{2}{*}{ Adsorbent } & \multicolumn{3}{|c|}{$\begin{array}{l}\text { Initial concentration } \\
(\mathrm{mg} / \mathrm{L})\end{array}$} & \multicolumn{3}{|c|}{$\begin{array}{l}\text { Adsorbed metal ion } \\
(\mathrm{mg} / \mathrm{g})\end{array}$} & \multicolumn{3}{|c|}{$\begin{array}{l}\text { Desorbed metal ion } \\
(\mathrm{mg} / \mathrm{g})\end{array}$} & \multicolumn{3}{|c|}{$\begin{array}{c}\text { Desorbed metal ion } \\
(\%)\end{array}$} \\
\hline & $\mathrm{Au}(\mathrm{III})$ & $\mathrm{Cu}(\mathrm{II})$ & $\mathrm{Ni}(\mathrm{II})$ & $\mathrm{Au}(\mathrm{III})$ & $\mathrm{Cu}(\mathrm{II})$ & $\mathrm{Ni}(\mathrm{II})$ & $\mathrm{Au}(\mathrm{III})$ & $\mathrm{Cu}(\mathrm{II})$ & $\mathrm{Ni}(\mathrm{II})$ & $\mathrm{Au}(\mathrm{III})$ & $\mathrm{Cu}(\mathrm{II})$ & $\mathrm{Ni}(\mathrm{II})$ \\
\hline \multirow{4}{*}{ 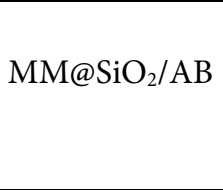 } & 20 & 0 & 0 & 17.00 & 0.00 & 0.00 & 12.37 & 0.00 & 0.00 & 72.76 & 0.00 & 0.00 \\
\hline & 20 & 20 & 20 & 14.37 & 13.03 & 13.94 & 9.85 & 0.31 & 0.90 & 68.56 & 2.38 & 6.47 \\
\hline & 20 & 40 & 20 & 17.65 & 12.97 & 17.95 & 9.45 & 0.79 & 0.80 & 53.56 & 6.09 & 4.48 \\
\hline & 20 & 20 & 40 & 17.78 & 16.48 & 11.29 & 9.45 & 0.25 & 0.40 & 53.15 & 1.53 & 3.56 \\
\hline \multirow{4}{*}{${\mathrm{MM} @ \mathrm{SiO}_{2} / \mathrm{TB}}$} & 20 & 0 & 0 & 9.26 & 0.00 & 0.00 & 6.55 & 0.00 & 0.00 & 70.74 & 0.00 & 0.00 \\
\hline & 20 & 20 & 20 & 17.67 & 16.88 & 17.23 & 14.25 & 1.11 & 1.96 & 80.61 & 6.58 & 11.37 \\
\hline & 20 & 40 & 20 & 17.90 & 36.52 & 12.71 & 11.93 & 0.45 & 2.16 & 66.63 & 1.24 & 16.99 \\
\hline & 20 & 20 & 40 & 17.66 & 15.35 & 36.62 & 12.58 & 0.54 & 2.25 & 71.25 & 3.53 & 6.15 \\
\hline
\end{tabular}

and various other metal ion concentrations. Adsorption selectivity is presented as a selectivity coefficient (coefficient distribution ratio of $\mathrm{Au}(\mathrm{III})$ to another ion) and calculated using Eq. (1).

From Table 4 could be known that the selectivity of $\mathrm{Au}(\mathrm{III})$ on $\mathrm{MM} @ \mathrm{SiO}_{2} / \mathrm{AB}$ and $\mathrm{MM} @ \mathrm{SiO}_{2} / \mathrm{TB}$ toward $\mathrm{Cu}(\mathrm{II})$ and $\mathrm{Ni}$ (II) is higher than 1 . It proves that these adsorbents adsorb $\mathrm{Au}(\mathrm{III})$ selectively toward other metals ion in the mixture. This is caused by the tendency of

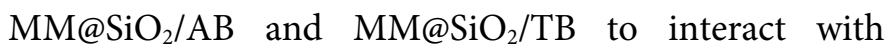
$\left[\mathrm{AuCl}_{4}\right]^{-}$anion electrostatically than with $\mathrm{Cu}$ (II) and $\mathrm{Ni}$ (II) resulting in electrostatic repulsion. It can be seen

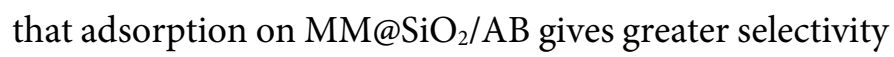

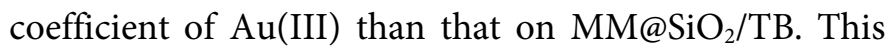
result is agreed with the adsorption data of $\mathrm{Au}(\mathrm{III})$ in a single metal ion system which $\mathrm{MM} @ \mathrm{SiO}_{2} / \mathrm{AB}$ has a higher capability to adsorbing $\mathrm{Au}(\mathrm{III})$.

\section{Desorption}

Desorption of $\mathrm{Au}(\mathrm{III}), \mathrm{Cu}(\mathrm{II})$ and $\mathrm{Ni}(\mathrm{II})$ metal ions

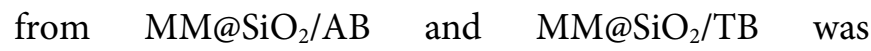
investigated by varying the concentration of $\mathrm{Cu}(\mathrm{II})$ and $\mathrm{Ni}(\mathrm{II})$ adsorbed on adsorbents while $\mathrm{Au}(\mathrm{III})$ concentration was made constant. A solution of $1 \mathrm{M}$ thiourea in $1 \mathrm{M} \mathrm{HCl}$ has been reported to yield the high percentage recovery of gold and the least dissolution of magnetic material particles [23].

Table 5 represents that desorption of $\mathrm{Au}(\mathrm{III})$ from

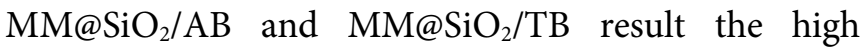
percentage of $\mathrm{Au}(\mathrm{III})$ desorbed (more than $53.15 \%$ ) and this value is higher than the percentage of $\mathrm{Cu}(\mathrm{II})$ and $\mathrm{Ni}$ (II) desorbed (less than 16.99\%). Based on hard-softacid-base (HSAB) theory, $\mathrm{Au}$ (III) as soft acid, could interact with $S$ of thiourea as a soft base through sharing of electrons involving covalent forces. This covalent 
bonding results in a stable complex between thiourea and $\mathrm{Au}$ (III) so that $\mathrm{Au}(\mathrm{III})$ tends to bind with thiourea than with amine groups on adsorbents surface. This phenomenon does not occur on $\mathrm{Cu}(\mathrm{III})$ and $\mathrm{Ni}(\mathrm{II})$ as intermediate acid (borderline) thus the amount of $\mathrm{Cu}(\mathrm{II})$ and $\mathrm{Ni}(\mathrm{II})$ desorbed is lower than that of $\mathrm{Au}(\mathrm{II})$.

\section{- CONCLUSION}

It can be concluded that 2-aminobenzimidazole and 1-(o-tolyl)biguanide modified silica have been successfully coated on the iron sand magnetic material using CPTS as a cross-linking agent. The $\mathrm{Au}(\mathrm{III})$ adsorption capacity of $\mathrm{MM@SiO} / \mathrm{AB}$ and that of $\mathrm{MM@SiO} / \mathrm{TB}$ are higher than that of $\mathrm{MM} / \mathrm{SiO}_{2}$. The adsorption of $\mathrm{Au}(\mathrm{III})$ on these adsorbents in single metal ion system fit Langmuir isotherm model and follow pseudo-second-order reaction. The selectivity adsorption test proves that $\mathrm{MM} @ \mathrm{SiO}_{2} / \mathrm{AB}$ and $\mathrm{MM} @ S i O_{2} / \mathrm{TB}$ have high selectivity towards $\mathrm{Au}(\mathrm{III})$ in a mixture of $\mathrm{Au}(\mathrm{III})$, $\mathrm{Cu}$ (II) and $\mathrm{Ni}$ (II). The desorption metal ions from adsorbents show that percentage of $\mathrm{Au}$ (III) adsorbed is higher than that of $\mathrm{Cu}$ (II) and that of $\mathrm{Ni}(\mathrm{II})$.

\section{- ACKNOWLEDGMENTS}

This work was funded by the Ministry of Research, Technology and Higher Education of Indonesia through research grant of Penelitian Berbasis Kompetensi (PBK), contract number: 1731/UN1/DITLIT/DIT-LIT/LT/2018.

\section{- REFERENCES}

[1] Shabbir, S., Lee, Y., and Rhee, H., 2015, Au(III) catalyst supported on a thermoresponsive hydrogel and its application to the A-3 coupling reaction in water, J. Catal., 322, 104-108.

[2] Kim, E.Y., Kim, M.S., Lee, J.C., and Pandey, B.D., 2011, Selective recovery of gold from waste mobile phone PCBs by hydrometallurgical process, J. Hazard. Mater., 198, 206-215.

[3] Firlak, M., Yetimoğlu, E.K., and Kahraman, M.V., 2014, Adsorption of $\mathrm{Au}(\mathrm{III})$ ions from aqueous solutions by thiol-ene photoclick hydrogels and its application to electronic waste and geothermal water, J. Water Process Eng., 3, 105-116.

[4] Arshadi, M., and Mousavi, S.M., 2015, Enhancement of simultaneous gold and copper extraction from computer printed circuit boards using Bacillus megaterium, Bioresource Technol., 175, 315-324.

[5] Aguado, J., Arsuaga, J.M., Arencibia, A., Lindo, M., and Gascón, V., 2009, Aqueous heavy metals removal by adsorption on amine-functionalized mesoporous silica, J. Hazard. Mater., 163 (1), 213221.

[6] Sakti, S.C.W., Narita, Y., Sasaki, T., Nuryono, and Tanaka, S., 2015, A novel pyridinium functionalized magnetic chitosan with $\mathrm{pH}$ independent and rapid adsorption kinetics for magnetic separation of $\mathrm{Cr}(\mathrm{VI})$, J. Environ. Chem. Eng., 3 (3), 1953-1961.

[7] Behbahani, M., Najafi, F., Amini, M.M., Sadeghi, O., Bagheri, A., and Hassanlou, P.G., 2014, Solid phase extraction using nanoporous MCM-41 modified with 3,4-dihydroxybenzaldehyde for simultaneous preconcentration and removal of gold(III), palladium(II), copper(II) and silver(I), $J$. Ind. Eng. Chem., 20 (4), 2248-2255.

[8] Li, X., Zhang, C., Zhao, R., Lu, X., Xu, X., Jia, X., Wang, C., and Li, L., 2013, Efficient adsorption of gold ions from aqueous systems with thioamidegroup chelating nanofiber membranes, Chem. Eng. J., 229, 420-428.

[9] Araghi, S.H., and Entezari, M.H., 2015, Aminofunctionalized silica magnetite nanoparticles for the simultaneous removal of pollutants from aqueous solution, Appl. Surf. Sci., 333, 68-77.

[10] Fotoohi, B., and Mercier, L., 2015, Some insights into the chemistry of gold adsorption by thiol and amine functionalized mesoporous silica in simulated thiosulfate system, Hydrometallurgy, 156, 28-39.

[11] Sakti, S.C.W., Siswanta, D., and Nuryono, 2013, Adsorption of gold(III) on ionic imprinted aminosilica hybrid prepared from rice hull ash, Pure Appl. Chem., 85 (1), 211-223.

[12] Hastuti, S., Nuryono, and Kuncaka, A., 2015, LArginine-modified silica for adsorption of gold(III), Indones. J. Chem., 15 (2), 108-115.

[13] Ebrahimzadeh, H., Tavassoli, N., Amini, M.M., Fazaeli, Y., and Abedi, H., 2010, Determination of 
very low levels of gold and palladium in wastewater and soil samples by atomic absorption after preconcentration on modified MCM-48 and MCM41 silica, Talanta, 81 (4-5), 1183-1188.

[14] Zhang, Y., Xu, Q., Zhang, S., Liu, J., Zhou, J., Xu, H., Xiao, H., and Li, J., 2013, Preparation of thiolmodified $\mathrm{Fe}_{3} \mathrm{O}_{4} @ \mathrm{SiO}_{2}$ nanoparticles and their application for gold recovery from dilute solution, Sep. Purif. Technol., 116, 391-397.

[15] Alizadeh, A., Khodaei, M.M., Beygzadeh, M., Kordestani, D., and Feyzi, M., 2012, Biguanidefunctionalized $\mathrm{Fe}_{3} \mathrm{O}_{4} / \mathrm{SiO}_{2}$ magnetic nanoparticles: An efficient heterogeneous organosuperbase catalyst for various organic transformations in aqueous media, Bull. Korean Chem. Soc., 33 (8), 2546-2552.

[16] Nuryono, N., Muliaty, E., Rusdiarso, B., Sakti, S.C.W., and Tanaka, S., 2014, Adsorption of Au(III), $\mathrm{Cu}$ (II) and $\mathrm{Ni}$ (II) on magnetite coated with mercapto groups modified rice hull ash silica, J. Ion Exch., 25 (4), 114-121.

[17] Nuryono, N., Rosiati, N.M., Rusdiarso, B., Sakti, S.C.W., and Tanaka, S., 2014, Coating of magnetite with mercapto modified rice hull ash silica in a onepot process, SpringerPlus, 3, 515.

[18] Fahmiati, Nuryono, and Suyanta, 2017,
Characteristics of iron sand magnetic material from Bugel beach, Kulon Progo, Yogyakarta, IOP Conf. Ser. Mater. Sci. Eng., 172 (1), 012020.

[19] Sui, D.P., Chen, H.X., Liu, L., Liu, M.X., Huang, C.C., Fan, H.T., 2016, Ion-imprinted silica adsorbent modified diffusive gradients in thin films technique: Tool for speciation analysis of free lead species, Talanta, 148, 285-291.

[20] Azmiyawati, C., Nuryono, and Narsito, 2014, Synthesis of disulfonato-silica hybrid from rice husk ash, JOMB, 3 (4), 301-305.

[21] Lin, Y.F., Chen, H.W., Chien, P.S., Chiou, C.S., and Liu, C.C., 2011, Application of bifunctional magnetic adsorbent to adsorb metal cations and anionic dyes in aqueous solution, J. Hazard. Mater., 185 (2-3), 1124-1130.

[22] Pacławski, K., and Fitzner, K., 2004, Kinetics of gold(III) chloride complex reduction using sulfur(IV), Metall. Mater. Trans. B, 35 (6), 10711085.

[23] Kraus, A., Jainae, K., Unob, F., and Sukpirom, N., 2009, Synthesis of MPTS-modified cobalt ferrite nanoparticles and their adsorption properties in relation to $\mathrm{Au}(\mathrm{III})$, J. Colloid Interface Sci., 338 (2), 359-365. 